\title{
Semen Characteristics in German Shepherd Dogs
}

\author{
I. Shalini* and D. Antoine \\ Department of Veterinary Gynaecology and Obstetrics, Rajiv Gandhi Institute of Veterinary \\ Education and Research, Puducherry - 605009, India \\ *Corresponding author
}

\begin{tabular}{|l|}
\hline Ke y w o r d s \\
Enzyme activity, \\
$\begin{array}{l}\text { Evaluation, GSD, } \\
\text { Membrane integrity, } \\
\text { Semen, Viability }\end{array}$ \\
\hline Article Info \\
\hline $\begin{array}{l}\text { Accepted: } \\
\text { 20 February } 2018 \\
\text { Available Online: } \\
\text { 10 March } 2018\end{array}$ \\
\hline
\end{tabular}

\section{A B S T R A C T}

A total of six German shepherd dogs were selected for Breeding Soundness Examination (BSE). Body condition score was evaluated on a scale of 1-9 and Testicular volume was measured by Vernier Caliper before semen collection. The method of semen collection was by digital manipulation. The biophysical and biochemical attributes of semen for GSD dogs was characterized. In GSD dogs, the testes were firm in texture and no other scrotal abnormality was noticed. The body condition score, testicular volume, volume of semen, colour, $\mathrm{pH}$, mass activity, initial motility, sperm concentration, live spermatozoa, total sperm abnormality, Intact acrosome and positive for HOS were $4.66 \pm 0.07,44.2 \pm 1.10 \mathrm{~cm}^{3}$, $8.68 \pm 0.47 \mathrm{ml}$, Opalescent, $6.25 \pm 0.04,3.16 \pm 0.06 \%, 83.3 \pm 0.79 \%, 376 \pm 13.6 \mathrm{millions} / \mathrm{ml}$, $86.3 \pm 0.78 \%, 7.25 \pm 0.86 \%, 79.0 \pm 0.83 \%$ and $74.8 \pm 0.72 \%$, respectively. The total protein, albumin, globulin, ALP and ACP were $2.98 \pm 0.23 \mathrm{~g} / \mathrm{dl}, 0.35 \pm 0.04 \mathrm{~g} / \mathrm{dl}, 2.66 \pm 0.22 \mathrm{~g} / \mathrm{dl}$, $7422 \pm 520 \mathrm{IU} / \mathrm{L}$ and $1264 \pm 33.0 \mathrm{IU} / \mathrm{L}$, respectively. In the present study, the biophysical and biochemical attributes of semen for GSD was characterized and compared with standard reference value for fertile dog semen. In the present study all the German Shepherd Dogs were fertile.

\section{Introduction}

The key aspects of Breeding Soundness Evaluation are body condition score, testicular volume and semen evaluation. Body condition score was used to assess the general health of dogs on a scale of $1-9$, where 1 refers to emaciated animal and 9 indicates grossly obese dog (Edney and Smith, 1986). Testicular biometry was calculated by measuring testicular length and width by using vernier caliper (Harriet et al., 2002). The most commonly used method for semen collection in dogs is by digital manipulation (Kutzler,
2005). Semen parameters such as semen volume, sperm concentration, motility, live and dead spermatozoa and sperm morphology in the whole ejaculate are frequently examined to assess the quality of semen (Gunzel-Apel, 1994). The functional integrity of the sperm plasma membrane is crucial for the viability and fertilizing ability of spermatozoa (Hafez, 1993). The Hypo-Osmotic swelling test by using distilled water has been effectively used to assess the functional integrity of sperm plasma membrane (Lomeo and Giambersio, 1991). The determination of intact acrosome is another essential tool to evaluate indirectly the 
fertilizing capacity of spermatozoa (Wells and Awa, 1970). The seminal plasma enzyme, alkaline phosphatase is primarily of testicular and epididymal origin. Another seminal plasma enzyme, the acid phosphatase is a biochemical marker, primarily related to the metabolic functions of spermatozoa and prostate diseases in dogs (King and Macpherson, 1966). Alkaline and acid phosphatases are good indicators of the secretary functions of the epididymis and prostate gland respectively (Tannenbaum, 1982). The objective of this study was to evaluate the biophysical and biochemical characteristics of semen and compare the semen quality with that of standard reference value of fertile dog semen.

\section{Materials and Methods}

\section{Experimental animals}

The experiment was performed on apparently healthy six GSD aged between 2 to 4 years maintained by pet owners of Puducherry. Body condition score on a scale of 1 to 9 was assessed before semen collection as per the method described by Laflamme (1997). The testicular volume was measured as per Vernier Caliper method and as per the formula adopted by Harriet et al., (2002). Semen from dog was collected by digital manipulation and stimulation of the Bulbus glandis (LindeForsbrg, 1991). A total of 36 ejaculates from six GSD were subjected to macroscopic and microscopic analysis.

\section{Experimental procedure}

\section{Volume and colour of the ejaculate}

A glass funnel fitted in a graduated measuring plastic tube was used to collect the ejaculate and the volume was directly measured on the graduated marks in the measuring tube (LindeForsberg, 1995). The colour was visually noticed as per the method described by (Feldman et al., 2004).

\section{pH and mass activity}

The $\mathrm{pH}$ of dog semen was measured by $\mathrm{pH}$ paper in the $\mathrm{pH}$ range from 5.0-8.0 (Freshman, 2002). The mass activity of spermatozoa was recorded immediately after semen collection by examining a drop of semen on a clean glass slide at 100x magnification without cover slip. Mass activity was evaluated on a scale of 0-5 as per the method described by Evans and Maxwell (1987).

\section{Initial motility}

The initial motility of spermatozoa was recorded immediately after semen collection by examining a drop of semen on a clean glass slide and diluted with one drop of Tris buffer kept at $37^{\circ} \mathrm{c}$ at $400 \mathrm{x}$ magnification with a coverslip. The initial motility was evaluated as per the method described by Gunzel-Apel (1994) and Feldman and Nelson (1996).

\section{Sperm concentration and sperm morphology}

Sperm concentration was calculated by haemocytometric method (Sorenson, 1976) and expressed in millions of spermatozoa per milliliter of semen. The sperm morphology was studied using nigrosin-eosin stained semen smear.

Nigrosin-eosin staining technique was adopted to identify the live and the dead spermatozoa. A total of 200 sperms will be observed in not less than 10 randomly selected microscopic fields per sample under 1000x magnification (Hancock and Rowlands, 1949). The percentage of abnormal sperm with head abnormality, proximal and distal protoplasmic droplet, deformed tail and total number of abnormal sperm were calculated. 


\section{Sperm membrane integrity}

\section{Hypo osmotic swelling test (HOST)}

The sperm plasma membrane integrity was assessed by a volume of $10.0 \mu \mathrm{l}$ of semen was added to $1 \mathrm{ml}$ of mono distilled water and incubated at $37^{\circ} \mathrm{C}$ for $5 \mathrm{~min}$. After incubation, 1 drop of the semen was placed on a glass slide covered with cover slip and evaluated under 1000x magnification. A total of 200 sperms were evaluated and percentages of swollen tail spermatozoa were calculated as per the method described by Lomeo and Giambersio (1991).

\section{Acrosome membrane integrity}

Acrosome cap integrity by using Giemsa stain was studied as per the method adopted by Watson (1975). The acrosome morphology was classified as intact, partial and completely lost acrosome as per the classification of Blom (1972).

\section{Seminal plasma separation}

The semen collected was centrifuged at 1000x $\mathrm{g}$ for $15 \mathrm{~min}$ at room temperature. The separated seminal plasma was centrifuged at 10,000x $\mathrm{g}$ for $10 \mathrm{~min}$ at room temperature and stored at $-80^{\circ} \mathrm{c}$ (Strzezek et al., 2015). The separated seminal plasma was used for estimation of biochemical constituents. The total protein, albumin, Alkaline and acid phosphatase in the seminal plasma were estimated by colorimetric method.

\section{Results and Discussion}

\section{Body Condition Score}

The Body condition score was between $4.00 \pm$ 0.00 and $5.00 \pm 0.00$ for German shepherd dogs. The BCS was $4.66 \pm 0.07$ for GSD (Table 1). In the present study, the mean body condition score was ideal and optimum for a breeding dog.

\section{Testicular Volume and Seminal attributes}

Testicular volume and volume of the ejaculate

The testicular volume ranged between 33.7 .00 \pm 0.00 and $52.6 .00 \pm 0.00 \mathrm{~cm}^{3}$ in GSD. The mean testicular volume was $44.2 \pm 1.10 \mathrm{~cm}^{3}$ for GSD. The volume of the ejaculate for German shepherd dogs was between $6.91 \pm 1.05$ to $12.3 \pm 0.98$. The mean volume of the ejaculate was $8.68 \pm 0.47 \mathrm{ml}(6.9-9.3 \mathrm{ml})$ for GSD (Table 1). The difference between GSD in testicular volume and volume of the ejaculate could be due to age and body size of the dog.

\section{Colour and pH of the semen}

The colour of the semen was uniformly opalescent in GSD. The $\mathrm{pH}$ of semen ranged between $6.00 \pm .00$ to $6.50 \pm 0.00$ in GSD. The mean $\mathrm{pH}$ of semen in GSD was $6.25 \pm 0.04$ (Table 1). Meyers-Wallen (1991) observed that good quality semen always slightly acidic and poor quality is generally neutral or slightly alkaline.

\section{Mass activity}

The mass activity of spermatozoa was ranged between $3.00 \pm 0.00$ to $4.00 \pm 0.00$ in GSD. The mean mass activity of spermatozoa for GSD was $3.16 \pm 0.06$ (Table 1). Santos et al., (2007) observed $4.57 \pm 0.11$ and Quintela et al., (2010) found $5.00 \pm 0.00$ on a scale of $0-5$ in fresh dog semen.

\section{Initial motility}

The Initial motility of spermatozoa was ranged between $80.0 \pm 0.00$ to $90.0 \pm 0.00 \%$ in GSD. The mean Initial motility was $83.3 \pm 0.79 \%$ 
for GSD (Table 1). Gunay et al., (2003) reported the initial motility of first ejaculate was $84.42 \pm 5.3 \%$ and second ejaculate was $82.42 \pm 4.7 \%$ in German shepherd dogs.

\section{Sperm concentration}

The concentration of the spermatozoa ranged between $290 \pm 25.91$ to $446 \pm 14.06$ millions and $\mathrm{ml}$ in fertile dogs. The sperm concentration was $376 \pm 13.6$ millions / $\mathrm{ml}$ for GSD (Table 1). The sperm concentration in the ejaculate is closely related to age of the animal, body weight, testicular weight and sexual activity (Amann, 1986).

\section{Sperm morphology}

The percentage of incidence of live spermatozoa ranged between $82.3 \pm 1.85$ to $91.1 \pm 1.72 \%$ in GSD. The percentage of live spermatozoa was $86.3 \pm 0.78 \%$ for GSD. Kurien et al., (2012) reported that the mean live sperm percentage recorded in dog semen was $85.67 \pm 0.81 \%$. The percentage of incidence of total sperm abnormality ranged between $3.83 \pm 0.70$ to $14.6 \pm 3.11 \%$ in GSD. The total sperm abnormality was $7.25 \pm$ $0.86 \%$ for GSD (Table 1; Fig. 1). Kurien et al., (2012) recorded the total abnormality of spermatozoa between $7-10 \%$ in dog semen.

Fig.1 Incidence of Live spermatozoa, total sperm abnormality, intact acrosome and HOS (+) sperms between GSD

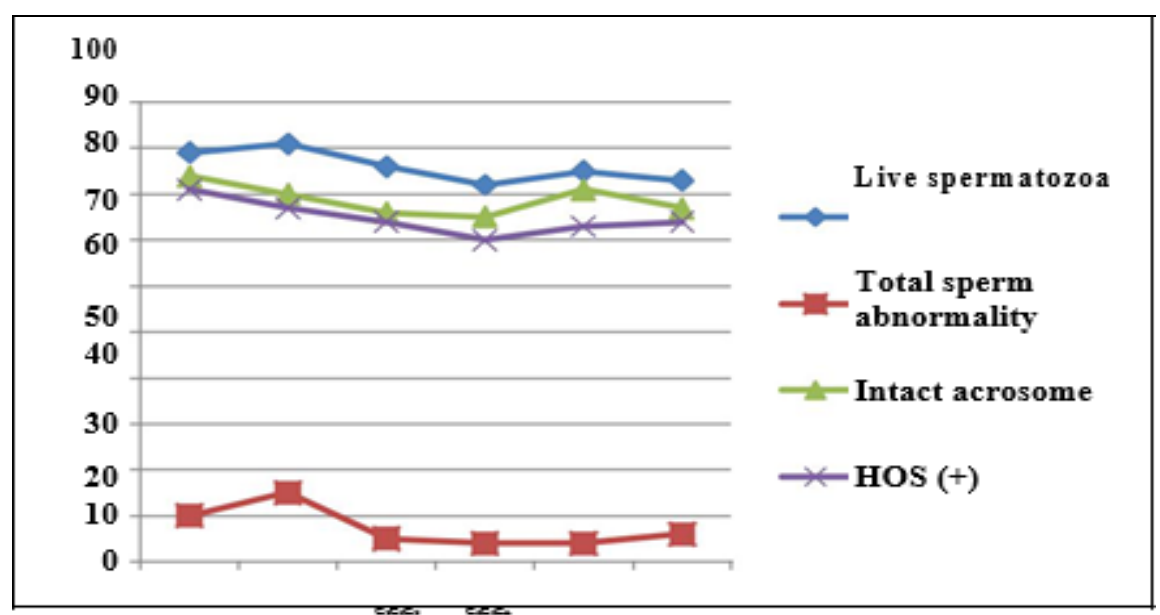

Fig.2 Alkaline and Acid phosphatase between GSD

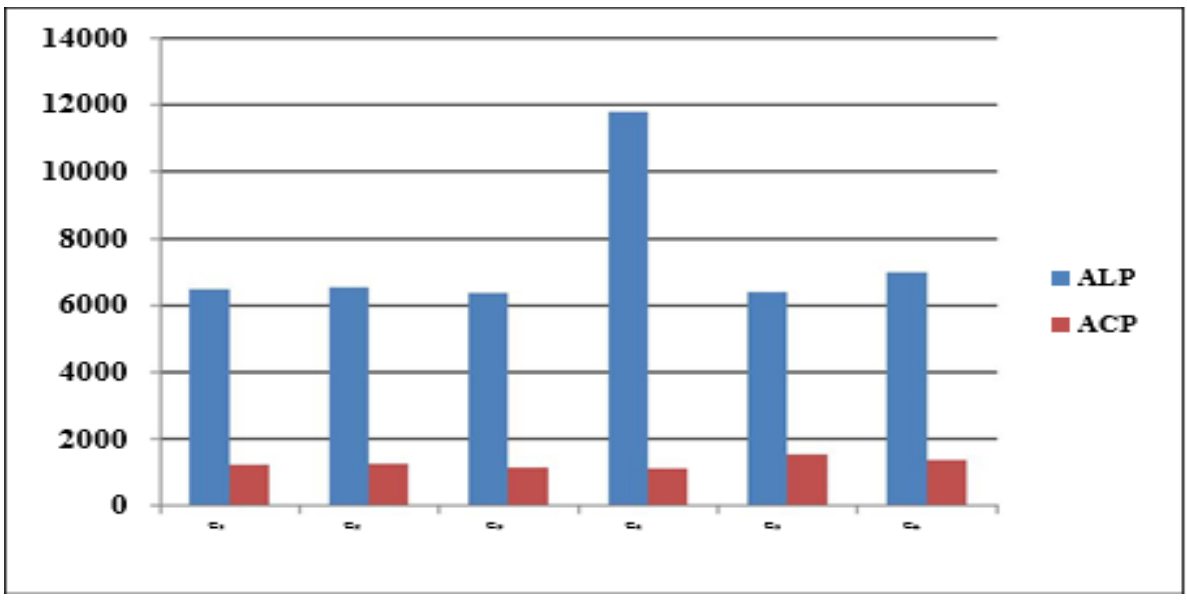


Table.1 BCS, Testicular volume and semen characteristics for German shepherd dogs

\begin{tabular}{|c|c|c|c|c|c|c|c|c|c|c|c|c|}
\hline \multirow[b]{2}{*}{ SI. No } & \multirow[b]{2}{*}{ Parameters } & & \multirow[b]{2}{*}{$\mathbf{G}_{\mathbf{1}}$} & & \multirow[b]{2}{*}{$\mathbf{G}_{2}$} & \multicolumn{4}{|c|}{ No. of ejaculate in dogs } & \multirow[b]{2}{*}{$\mathbf{G}_{5}$} & & \multirow[b]{2}{*}{$\mathbf{G}_{6}$} \\
\hline & & & & & & & $\mathbf{G}_{3}$ & & $\mathbf{G}_{4}$ & & & \\
\hline & & & $n=6$ & & $n=6$ & & $n=6$ & & $n=6$ & $n=6$ & & $n=6$ \\
\hline 1 & Body Condition Score & 5.00 & \pm 0.00 & 4.00 & \pm 0.00 & 4.00 & \pm 0.00 & 5.00 & \pm 0.00 & $5.00 \pm 0.00$ & 5.00 & \pm 0.00 \\
\hline 2 & Testicular Volume $\left(\mathrm{cm}^{3}\right)$ & 47.2 & \pm 0.00 & 33.7 & \pm 0.00 & 38.4 & \pm 0.00 & 50.1 & \pm 0.00 & $52.6 \pm 0.00$ & 43.4 & \pm 0.00 \\
\hline 3 & Volume of semen (ml) & 8.91 & $\pm 1.03^{\mathrm{ab}}$ & 12.3 & $\pm 0.98^{\mathrm{a}}$ & 7.66 & $\pm 0.42^{\mathrm{b}}$ & 9.33 & $\pm 0.96^{\mathrm{ab}}$ & $6.91 \pm 1.05^{\mathrm{b}}$ & 6.91 & $\pm 1.05^{\mathrm{b}}$ \\
\hline 4 & Colour of semen & \multicolumn{2}{|c|}{ Opalescent } & \multicolumn{2}{|c|}{ Opalescent } & \multicolumn{2}{|c|}{ Opalescent } & \multicolumn{2}{|c|}{ Opalescent } & Opalescent & \multicolumn{2}{|c|}{ Opalescent } \\
\hline 6 & Mass Activity of spermatozoa & 3.00 & \pm 0.00 & 3.00 & \pm 0.00 & 3.00 & \pm 0.00 & 3.00 & \pm 0.00 & $3.00 \pm 0.00$ & 4.00 & \pm 0.00 \\
\hline 7 & Initial Motility of spermatozoa (\%) & 90.0 & \pm 0.00 & 90.0 & \pm 0.00 & 80.0 & \pm 0.00 & 80.0 & \pm 0.00 & $80.0 \pm 0.00$ & 80.0 & \pm 0.00 \\
\hline 8 & Sperm Concentration (millions/ ml) & 420 & $\pm 31.94^{b}$ & \multicolumn{2}{|c|}{$388 \pm 46.93^{\mathrm{ab}}$} & \multicolumn{2}{|c|}{$380 \pm 18.80^{\mathrm{ab}}$} & 290 & $\pm 25.91^{\mathrm{a}}$ & $333 \pm 10.72^{\mathrm{ab}}$ & \multicolumn{2}{|c|}{$446 \pm 14.06^{\mathrm{b}}$} \\
\hline 9 & Live Spermatozoa $(\%)$ & 89.1 & $\pm 1.85^{\mathrm{bd}}$ & 91.1 & $\pm 1.72^{\mathrm{bc}}$ & 86.5 & $\pm 1.05^{\mathrm{abc}}$ & 82.3 & $\pm 1.85^{\mathrm{ae}}$ & $85.1 \pm 1.24^{\mathrm{abc}}$ & 83.5 & $\pm 1.52^{\mathrm{ad}}$ \\
\hline 10 & Total Sperm Abnormality (\%) & 9.83 & $\pm 1.35^{\text {abcde }}$ & 14.6 & $\pm 3.11^{\mathrm{a}}$ & 5.50 & $\pm 0.61^{\mathrm{bc}}$ & 3.83 & $\pm 0.70^{c}$ & $4.00 \pm 0.44^{\mathrm{cd}}$ & 5.66 & $\pm 0.84^{\mathrm{ce}}$ \\
\hline 11 & Intact Acrosome (\%) & 84.5 & $\pm 0.99^{\mathrm{a}}$ & 80.0 & $\pm 1.65^{\text {abcd }}$ & 76.5 & $\pm 2.26^{\mathrm{bc}}$ & 75.3 & $\pm 1.80^{c}$ & $80.7 \pm 1.77^{\mathrm{abc}}$ & 77.0 & $\pm 1.46^{\mathrm{cd}}$ \\
\hline
\end{tabular}

Mean value having different super script within same row differ significantly $(\mathrm{P}<0.05)$

Table.2 Seminal plasma biochemical parameters for German shepherd dogs

\begin{tabular}{|c|c|c|c|c|c|c|c|c|c|c|c|c|c|}
\hline \multirow[b]{2}{*}{ SI. No } & \multirow[b]{2}{*}{ Parameters } & & \multirow[b]{2}{*}{$\mathbf{G}_{1}$} & & \multirow[b]{2}{*}{$\mathbf{G}_{2}$} & \multicolumn{4}{|c|}{ No. of ejaculate in dogs } & & \multirow[b]{2}{*}{$\mathbf{G}_{5}$} & & \multirow[b]{2}{*}{$\mathbf{G}_{6}$} \\
\hline & & & & & & & $\mathbf{G}_{3}$ & & $\mathbf{G}_{4}$ & & & & \\
\hline & & & $n=6$ & & $n=6$ & & $n=6$ & & $n=6$ & & $n=6$ & & $n=6$ \\
\hline 1 & Total Protein $(\mathrm{g} / \mathrm{dl})$ & 2.56 & \pm 0.14 & 3.41 & \pm 0.17 & 2.15 & \pm 0.47 & 3.10 & \pm 0.81 & 4.08 & \pm 0.90 & 2.60 & \pm 0.38 \\
\hline 2 & Albumin (g/dl) & 0.23 & $\pm 0.02^{\mathrm{ac}}$ & 0.35 & $\pm 0.08^{\mathrm{ac}}$ & 0.16 & $\pm 0.03^{\mathrm{a}}$ & 0.33 & $\pm 0.09^{\mathrm{ac}}$ & 0.66 & $\pm 0.19^{b c}$ & 0.35 & $\pm 0.09^{\mathrm{ac}}$ \\
\hline 3 & Globulin (g/dl) & 2.33 & \pm 0.14 & 3.06 & \pm 0.23 & 1.98 & \pm 0.46 & 2.76 & \pm 0.81 & 3.41 & \pm 0.82 & 2.41 & \pm 0.33 \\
\hline 4 & ALP (IU/L) & 6489 & $\pm 391.7^{\mathrm{a}}$ & 6542 & $\pm 272.6^{\mathrm{ac}}$ & 6361 & $\pm 342.6^{\mathrm{ad}}$ & \multicolumn{2}{|c|}{$11780 \pm 1133^{b}$} & \multicolumn{2}{|c|}{$6390 \pm 2208^{\mathrm{ae}}$} & \multicolumn{2}{|c|}{$6971 \pm 516.8^{\text {af }}$} \\
\hline 5 & $\mathrm{ACP}(\mathrm{IU} / \mathrm{L})$ & 1227 & $\pm 30.01^{\mathrm{a}}$ & 1254 & $\pm 64.72^{\mathrm{ab}}$ & 1130 & $\pm 16.39^{\mathrm{ac}}$ & \multicolumn{2}{|c|}{$1108 \pm 70.45^{\mathrm{ad}}$} & 1513 & $\pm 112.6^{\mathrm{b}}$ & \multicolumn{2}{|c|}{$1353 \pm 14.50^{\mathrm{ab}}$} \\
\hline
\end{tabular}

Mean value having different super script within row differ significantly $(\mathrm{P}<0.05)$. 
Table.3 Characterization of biophysical and biochemical parameters in fertile dogs

\begin{tabular}{|c|c|c|c|}
\hline \multirow[t]{2}{*}{ SI. No } & \multirow[t]{2}{*}{ Semen parameters } & Fertile dogs & Reference \\
\hline & & $($ Mean $\pm \mathrm{SE})$ & values \\
\hline 1 & Volume (ml) & $8.68 \pm 0.47$ & $1.91-8.68$ \\
\hline 2 & Colour & Opalescent & Opalescent \\
\hline 3 & $\mathrm{pH}$ & $6.25 \pm 0.04$ & $6.0-6.5$ \\
\hline 4 & Mass activity & $3-4$ & $3-4$ \\
\hline 5 & Initial motility (\%) & $83.3 \pm 0.79$ & $78.30-85.00$ \\
\hline 6 & Sperm concentration (millions/ml) & $376 \pm 13.60$ & $273-598$ \\
\hline 7 & Live spermatozoa $(\%)$ & $86.3 \pm 0.78$ & $82.20-93.10$ \\
\hline \multirow[t]{3}{*}{8} & Total sperm abnormality (\%) & $7.25 \pm 0.86$ & $5.60-11.50$ \\
\hline & Sperm membrane integrity of & & \\
\hline & spermatozoa & & \\
\hline 9 & Intact acrosome $(\%)$ & $79.0 \pm 0.83$ & $75-85.10$ \\
\hline \multirow[t]{3}{*}{10} & HOS positive spermatozoa (\%) & $74.8 \pm 0.72$ & $70-82.10$ \\
\hline & Biochemical constituents in the & & \\
\hline & seminal plasma & & \\
\hline 11 & Total protein $(\mathrm{g} / \mathrm{dl})$ & $2.98 \pm 0.23$ & $1.21-2.98$ \\
\hline 12 & Albumin $(\mathrm{g} / \mathrm{dl})$ & $0.35 \pm 0.04$ & $0.17-0.35$ \\
\hline 13 & Globulin (g/dl) & $2.66 \pm 0.22$ & $0.98-2.66$ \\
\hline 14 & Alkaline phosphatase (IU/L) & $7422 \pm 520$ & $5758-8767$ \\
\hline 15 & Acid phosphatase (IU/L) & $1264 \pm 33.00$ & $871-1367$ \\
\hline
\end{tabular}

\section{Sperm membrane integrity}

The percentage of incidence of intact acrosome ranged between $75.3 \pm 1.80$ to 84.5 $\pm 0.99 \%$ in GSD. The intact acrosome was $79.0 \pm 0.83 \%(75-85 \%)$ for GSD (Table 1; Fig. 1). The results are closely related to Umamageswari et al., (2012) who observed $76.83 \pm 2.63 \%$ in fresh dog semen. The incidence of HOS positive spermatozoa was between $70.1 \pm 0.84$ to $80.6 \pm 0.76$ in GSD. The HOS positive spermatozoa were $74.8 \pm$ $0.72 \%$ (70 to $80 \%$ ) for GSD (Table 1; Fig. 1). Paulo (2011) reported 88-97\% HOS positive sperms in fresh dog semen.
Biochemical constituents in the seminal plasma

Total protein, albumin and globulin

The total protein level in seminal plasma was between $2.15 \pm 0.47$ to $4.08 \pm 0.90 \mathrm{~g} / \mathrm{dl}$ for GSD. The total protein level was $2.98 \pm 0.23$ $\mathrm{g} / \mathrm{dl}$ for GSD. The total protein concentration in the seminal plasma of mixed breeds (GSD and Rottweiler) was between 1.88 to $2.3 \mathrm{~g} / \mathrm{dl}$ (Aquino cortez, 2003 and Motheo, 2014) which was in close agreement with the present study. The albumin level in seminal plasma was between $0.16 \pm 0.03$ to $0.66 \pm$ 
$0.19 \mathrm{~g} / \mathrm{dl}$ in GSD. The albumin level was 0.35 $\pm 0.04 \mathrm{~g} / \mathrm{dl}$ for GSD. The globulin level in seminal plasma was between $1.98 \pm 0.46$ to $3.06 \pm 0.23 \mathrm{~g} / \mathrm{dl}$ in GSD. The globulin level was $2.66 \pm 0.22 \mathrm{~g} / \mathrm{dl}$ for GSD (Table 2).

\section{Alkaline and Acid phosphatase}

The alkaline phosphatase level in seminal plasma was between $6361 \pm 342.6$ to 11780 $\pm 1133 \mathrm{IU} / \mathrm{L}$ in GSD. The ALP level was 7422 $\pm 520 \mathrm{IU} / \mathrm{L}$ for GSD. The acid phosphatase level in seminal plasma ranged between 1108 \pm 70.45 to $1513 \pm 112.6 \mathrm{IU} / \mathrm{L}$ in GSD. The ACP level was $1264 \pm 33.0 \mathrm{IU} / \mathrm{L}$ for GSD (Table 2; Fig. 2). Gunay et al., (2003) reported that the alkaline phosphatase level in seminal plasma was $4189 \pm 526.1 \mathrm{IU} / \mathrm{L}$ in first ejaculate and $3521 \pm 414.0$ in second ejaculate. Strzezek et al., (2015) reported that the acid phosphatase level in the seminal plasma was $811.06 \pm 141.64 \mathrm{IU} / \mathrm{L}$ in autumn and $1774.05 \pm 171.08 \mathrm{IU} / \mathrm{L}$ in summer for fertile dogs.

The high levels of ALP and ACP in the present study indicate that the epididymal and prostate gland functional integrity was good. The alkaline and acid phosphatase level in the seminal plasma reflected the physiological function of epididymal and prostate gland. However the level of alkaline and acid phosphatase in the seminal plasma was high in fertile dog semen comparable to that of reference value for fertile dog semen (Johnston, 1991).

The biophysical and biochemical characteristics of all fertile dog semen mentioned in Table 3 were comparable to that of previous reports on fertile dogs semen (Guney et al., 2003, Domoslawska et al., 2013 and Strzezek et al., 2015).

In the present study, the biophysical and biochemical attributes of semen for GSD was characterized and compared with that of reference value of fertile dog semen. Significant difference was recorded in volume of the ejaculate, sperm concentration, live spermatozoa, total sperm abnormality, percentage of intact acrosome and HOS positive sperms, albumin, alkaline and acid phosphatase within the same breed of GSD. It can be concluded that the difference between biophysical and biochemical characteristics of GSD semen could be due to age, body weight and nutritional management. However there is a difference between GSD, the biophysical and biochemical characteristics of GSD semen were fertile.

\section{References}

Amann, R. P., 1986. Reproductive Physiology and Endocrinology of the dog. In: Current Therapy in Theriogenology, 2nd ed. WB Saunders Co, pp. 532-538.

Aquino - cortez, A., 2003. Avaliação dos componentes bioquímicos do liquid prostáticoesuas correlações com a qualidade espermática canina.79f. Dissertação (Mestrado em Ciências Veterinárias) - Programa de PósGraduação em Ciências Veterinárias, Universidade Estadual do Ceará, CE.

Blom, E., 1972. The ultrastructure of some characteristics sperm defects and a proposal for a new classification of the bull spermiogram. In: Atti dell VII Symposium Int. Zoo. technia, Milan, 125-135.

Domosławska, A., Sławomir Zduńczy, k., Wojciech Niżańskil., and Tomasz Janowski. 2013. Assessment of semen quality in infertile dogs using computerassisted sperm analysis by the Hamilton-Thorne Semen Analyser. Bull. Vet. Inst. Pulawy, 57: 429-432.

Edney, A.T.B., and Smith, P.M. 1986. Study of obesity in dogs visiting veterinary 
practices in the United Kingdom. Vet. Rec, 118: 391-396.

Evans, G., and Maxwell, W. M. C. 1987. Salamons' artificial insemination of sheep and goats. Butter worths, Sydney.

Feldman, E.C., and Nelson, R.W. 1986. Clinical and Diagnostic evaluation of the male reproductive tract In: Canine and feline endocrinology and reproduction. Philadelphia, W.B. Saunders, 673-690.

Freshman, J.L., 2002. Semen collection and evaluation. Clinical Tech. Small Anim. Pract, 17(3): 104- 107.

Gunay, U., Polat, U., Gunes, N., Soylu, M.K., and Kil, F. 2003. The effects of shortinterval ejaculation on semen quality and some biochemical parameters in dogs. Revue. med.vet, 154: 459-62.

Gunzel-Apel, A.R., Terhaer, P., and Waberski, D. 1994. Hoden Ejakulatbeschafenheit fertile Rudenunters chiedlicher Korpergewichte. dimensionen, Kleintierpraxis, and 39: 483-486

Hafez, E.S.E., 1993. Reproduction in farm animals. Semen evaluation, Lea and Febiger, p. 405- 423.

Hancock, J.L., and Rowlands, I.W. 1949. The physiology of reproduction in the dog. Vet.Rec, 6: 771.

Harriet, J.P., Diamond, D.A., Canzio, J.D., Zurakowski, D., Borer, J.G., and Atala, A. 2002. Testicular volume: Comparison of orchidometer and US measurements in dogs. Radiology, 22: 114-119.

Johnston, S.D., (1991). Performing a complete canine semen evaluation in a small and animal hospital. Vet. Clin. North. Am. Small. Anim. Pract, 3: 54555.

King, G.J., and Macpherson, J.W. 1966. Alkaline and acid phosphatase activity, $\mathrm{pH}$ and osmotic pressure of boar semen. Canadian Journal of Comparative
Medicine and Veterinary Science, 30: 304-307.

Kurien, M.O., Katheresan, D., Atheresan, Selvaraju, M., Elvaraju, and Pattabiraman, S.R. 2012. Macroscopic, microscopic and bio-chemical characteristics of fresh dog semen. Indian Journal of Animal Reproduction, 33(1): 18-20.

Kutzler, M.A. 2005. Semen collection in the dog. Theriogenology, 64(3): 747-754.

Laflamme, D.P. 1997. Development and validation of a body condition score system for Dogs. Canine Practice, 22: 10-15.

Linde-Forsberg, C. 1991. Achieving Canine Pregnancy using frozen or chilled extended semen. Veterinary Clinics of North Am. Small Anim. Pract, 21: 467485.

Lomeo, A.M., and Giambersio, A.M. 1991. Water test: a simple method to assess sperm- membrane integrity. Int. Androl, 14: 278-282.

Meyers-Wallen, V.N. 1991. Clinical approach for evaluating dogs with azoospermia or aspermia. Vet. Clin. North. Am. Small. Anim. Pract, 21: 609-633.

Motheo, T.F. 2014. Semen parameters and seminal plasma protein and biochemical profiles of dogs with benign prostatic hyperplasia after botulinum toxin type A intraprostatic injection. Ciência Rural, 44(6): 1113-1118.

Paulo Alexandre Paulo Borges. 2011. Comparison of canine sperm quality under different temperature storage. Mestrado Integrado em Medicina Veterinaria, Universidade de tras-osmontes E alto douro vila real, Part II, 30-37.

Quintela, A.T., Oliveira, I.R.S., Souza, A.O., Gusmão, A.L., and Silva, A.R. 2010. Water induced hypo-osmotic test for the evaluation of canine sperm 
membrane integrity. Anim. Reprod, 7(2): 70-74.

Santos, I.W., Binsfeld, L.C., Weiss, R.R., KozicKi, L.E., Rochadelli, R.L., Resende, M.V., and Hossepian Delima, V.F.M. 2007. Cryopreservation of dog spermatozoa: effect of bovine serum albumin on acrosomal integrity and pregnancy rates after artificial insemination. Archie. Vet. Sci, 11: 4754.

Sorensen, A. 1976. Repro Lab: A Laboratory Manual for Animal Reproduction. Ames, IA: Kendall/Hunt Publishing. Strzeżek, R., Koziorowska-Gilun, M., Kiełczewski, K., and Kordan, W. 2015. Effect of dialysis of dog semen on sperm characteristics and some biochemical components of seminal plasma. J. Vet. Sci, 18: 447-448.

Tannenbaum, M. 1982. The prostate cell as a secretory factory of acid phosphatase. Annals New York Academy of Science, 390: $142-145$.

Umamageswari, J., Cecilia joseph, Kulasekar, k., Kalatharan, J., Sridevi, P. 2012. Assessment of acrosomal integrity of dog spermatozoa using spermac staining technique. Ind. Journ. Anim. Reprod, 33(2): 51.

Watson, P.F. 1975. Use of Giemsa stain to detect changes in acrosomes of frozen ram spermatozoa. Vet. Rec, 97: 12-15.

Wells, M.E., and Awa, O.A. 1970. New technique for assessing acrosomal characteristics of spermatozoa. J. Dairy. Sci, 53: 227-232.

\section{How to cite this article:}

Shalini, I. and Antoine, D. 2018. Semen Characteristics in German Shepherd Dogs. Int.J.Curr.Microbiol.App.Sci. 7(03): 2304-2312. doi: https://doi.org/10.20546/ijcmas.2018.703.270 